\title{
THE EFFECTIVENESS OF GLUCOMANNAN AND NANO ACTIVATED-CARBON AS HYPERCHOLESTEROL- LOWERING AGENTS
}

\author{
Gunawan Pasaribu*, Totok K. Waluyo, Gustan Pari, and Novitri Hastuti \\ Forest Products Research and Development Center \\ Jl. Gunung Batu No 5. Bogor, Jawa Barat, Indonesia
}

Received: 25 April 2020, Revised: 29 October 2020, Accepted: 29 October 2020

THE EFFECTIVENESS OF GLUCOMANNAN AND NANO ACTIVATED-CARBON AS HYPERCHOLESTEROL-LOWERING AGENTS. Porang (konjac) plants have long been used as a food source and traditional medicine. Glucomannan derived from porang has been utilised for various uses such as antidiabetic and antihypercholesterolemia agent. This paper studies the mixture of porang flour and nano activated-carbon and its effect on the cholesterol activity of rats. The mixture of porang and activated carbon were subjected to test for male Sprague Dawley rats to test the antihypercholesterolemia activity. The result showed that concerted anticholesterol activity of porang and nano activated-carbon revealed the cholesterol level decreases in rat's blood. However, the different treatments of unleached and leached porang either leached porang and nano activated-carbon applied in the experiments showed that the levels of cholesterol decrease were slightly different (16-18\%). Low glucomannan content as the alleged anticholesterol agent was regarded quite effective in lowering the cholesterol level in rat's blood and comparable with those of simvastatin which achieved 18\% reduction. Therefore, it indicates potential utilisation as a functional food for a cholesterol-lowering agent. The involvement of activated carbon in the alleged anticholesterol agent (leached porang flour) did little in enhancing the cholesterol level decrease in rat's blood. The glucomannan in both leached porang flour and leached porang flour + nano activated-carbon shows potential utilisation as an anticholesterol agent. Yet, raw (unleached) porang is prospectively potential as a functional food for cholesterol-lowering.

Keywords: Porang, anticholesterol, nano activated-carbon, glucomannan

EFEKTIVITAS GLUKOMANAN DAN NANO KARBON AKTIF SEBAGAI AGEN PENURUN KOLESTEROL. Tanaman porang (konjak) telah lama digunakan sebagai sumber makanan dan obat tradisional. Glukomanan yang berasal dari tanaman tersebut telah digunakan untuk. berbagai kegunaan sebagai antidiabetes dan juga sebagai antibiperkolesterol. Tujuan daripenelitian ini adalah untuk menguji aktivitas kolesterol pada tikus melalui perlakuan kombinasi tepung porang dan nano karbon aktif. Kombinasi porang dan nano karbon aktif diuji pada tikus jantan strain Sprague Dawley untuk menguji aktivitas antihiperkolesterolemia. Hasilnya menunjukkan babwa aktivitas antikolesterol porang dan nano karbon aktif menunjukean penurunan tingkat kolesterol dalam darah tikus. Namun, perlakuan yang berbeda antara porang tanpa pencucian dan porang dengan pencucian dengan nano karbon aktif menunjukean babwa penurunan kadar kolesterol sedikit berbeda (16-18\%). Kandungan glukomanan yang rendah dianggap cukup efektif dalam menurunkan kadar kolesterol dalam darah tikus, dibandingkan dengan kontrol positif (simvastatin); keduanya mencapai penurunan 18\%; sebingga menunjuk.kan potensi pemanfaatanny a sebagai makanan fungsional untuk, menurunkan kolesterol. Pengaruh nano karbon aktif dalam meningkatkan aktivitas antibiperkolesterolemia (tepung porang yang dicuci) ternyata tidak banyak membantu dalam meningkatkan penurunan kadar kolesterol dalam darah tikus. Glukomanan dalam tepung porang yang dicuci dan tepung porang yang dicuci + nano karbon aktif menunjuk.kan potensi pemanfaatannya sebagai agen antihiperkolesterol. Namun, porangyang tidak dicuci berpotensi sebagai makanan fungsional untuk menurunkan kolesterol.

Kata kunci: Porang, antibiperkolesterol, nano karbon aktif, glukomanan

*Corresponding author: gun_pa1000@yahoo.com 


\section{INTRODUCTION}

Amorphophallus muelleri, locally called porang or iles kuning, is one of potential glucomannan source in Indonesia (Yanuriati, Marseno, Rochmadi, \& Harmayani, 2017). They are prevalent as flour forms and could be used for various utilization, such as for food, industry, and health products. Porang plants are widely planted by the community and managed by Perum Perhutani across East Java, such as Jember, Nganjuk, Padangan, Saradan, Bojonegoro and Madiun. The total area of land reaches 1605.3 ha (Indriyani etal., 2010). Purified porang flour could be ingeniously converted into specific products for the manufactured (processed) items, such as specific type of food, including noodles, tofu and low-calorie artificial rice, a mixture for industrial raw materials, basic ingredients for film industries, and refreshment drink (Tester \& Al-Ghazzewi, 2017). Chua et al. (2010) mentioned that glucomannan could afford potential health benefits, owing to its efficacious healing performances, such as anti-obesity activity, anti-hyperglycemic and hypercholesterolemia activities, laxative effect, prebiotic activity, and anti-inflammatory activity.

Nowadays, many people are very concerned about a healthy lifestyle. Besides, consumers are very interested in functional food associated with human health. Not only can such food serve as a source of energy and nutrition, but it should also perform physiological functions needed by the human body for maintaining their health. One of the potential functional foodstuffs is porang (konjac). This stuff product exhibits a high dietary fiber and being low in calorie (Directorate-General for Food Crops, 2013).

Consuming glucomannan which is prevalently contained in porang/konjac or depolymerised glucomannan, is remarkably good for maintaining human health. The mannans could provide several health benefits in the human body. The ability of mannans, especially konjac glucomannans, to prevent specific pathogens including Escherichia coli from adhering to the gut or bladder mucosa, particularly in the human body, is highlighted or put to thorough attention. Other benefits associated with the local gut environment are discussed together with more systemic effects in and on other organs. The glucomannans could be an option for therapeutic tools in curing a wide range of physiological disorders such as diverticulitis and Crohn's disease or ulcerative colitis (Tester \& Al-Ghazzewi, 2013). Furthermore, a study by González-Torres et al. (2016) revealed that cholesterolemia was lower in glucomannan and glucomannan/spirulina treatment in rats. Glucomannan has been approved as generally regarded as safe (GRAS) food additive and had been approved by related agencies on food and health regulation in the USA, Canada and European Commission (Tester \& Al-Ghazzewi, 2017).

On the other hand, nanotechnology has been applied to improve the effectiveness of drug delivery, movement, and efficacy in the human body. One of the nano products which have been used in the drug delivery system is nanocarbon. Nanocarbon derived from bamboo charcoal showed good performance in delivering Eucommia ulmoides extract with cumulative release rate was $70.67 \%$ and in vitro anticancer study of this nano carbon delivery system showed the inhibition rate against HCT116 cancer cells was 23\% (Zeng, Zhang, \& Huang, 2017). Carbon nanotubes have been used for medicine such as for chemotherapy drug delivery, for stem cell-related therapies, and thermal destruction of tumours (Shao et al., 2013). Furthermore, (Liu et al., 2010) said that carbon nanotube-based drug delivery had shown promises in 2 various in vitro and in vivo experiments including the delivery of small interfering RNA (siRNA), paclitaxel and doxorubicin. Meanwhile, the carbon activation using thermal or chemical method is known to create well-developed microstructures and porosity, as well as surface functionality (Huang et al., 2018).

The utilisation of activated carbon nanoparticles exhibited efficient intracellular delivery of molecules while maintaining high 
cells viability close to $100 \%$ (Sengupta, Kelly, Dwivedi, Thadhani, \& Prausnitz, 2014). The prominent properties of nanocarbon, i.e. high specific area and porosity, high adsorption capacity and hierarchical porous structure, make them a good candidate as a carrier material (Huang et al., 2018). Among the carbonaceous materials, biomass-based activated carbon is attracting because of its unique internal structure having regularly interconnected mesopores, high surface area, low mass density, exceptional chemical stability, low cost and environmental friendly (Jain \& Tripathi, 2015).

In this study, the synergy of porang flour, which emerged into nano activated-carbon derived from biomass was observed. The use of nano-activated carbon and porang flour which containing glucomannan as an anticholesterol agent is predicted to be able to enhance antihypercholesterolemia activity as tested in rat body as well as the implantation of glucomannan in the potential active site. This study aims to evaluate the concerted antihypercholesterolemia activity of porang flour and nano activated-carbon. The commercial antihypercholesterol (simvastatin) was used in this study as a comparison.

\section{MATERIAL AND METHOD}

\section{A. Materials}

Porang (Amorphophallus muelleri) pieces as originally already procured in chip shape were indigenous from East Java. Activated carbon was made from charcoal pine waste.

\section{B. Methods}

\section{Preparation of Porang's Flour}

Porang flour which was used in this study was generated from the species Amorphophallus muelleri. Porang flour was prepared based on our previous research. Porang tubers were sliced to make chip. The dried chip was ground to get the unbleached flour. Then unbleached flour was purified using ethanol $50 \%$ and $\mathrm{NaHSO}_{3}$ $2 \%$ to get leached flour. (Pasaribu, Waluyo, Hastuti, Pari, \& Sahara, 2016). Glucomannan content was measured based on Indonesia's National Standard (SNI 7939, 2013).

\section{Preparation of Activated Carbon}

The nano activated carbon used in this experiment was prepared through the activation process from pine charcoal by a thermal method. The charcoal was activated in the retort at $800^{\circ} \mathrm{C}$ for 90 minutes (Pari, 1999). The activation intended mainly to remove the impurities (e.g. fat, residual high-boiling volatile matters, and impurities materials other than wood/lignocellulosic materials, such as dust, tiny sand particles, and dirt), thereby clearing its surface and enhancing its available pores numerously. Afterwards, as-prepared activated charcoal was ground mechanically; therefore, the size reduced vigorously to very tiny particles and denoted as nano activated-carbon. The resultant nano activated-carbon was characterised microscopically, and its properties were evaluated by refers to the Indonesian standard (SNI 06-7370, 1995).

\section{Combination of Porang and Nano Activated-Carbon}

The nano-activated carbon and porang flour were mixed in the ratio of $90 \%(\mathrm{w} / \mathrm{w})$ of porang flour and $10 \%$ of nano activatedcarbon. The composition selection was made based on the results of previous studies which showed good results.

\section{Antihypercholesterolemia Activity Test}

As many 42 healthy living male rats as of Sprague Dawley strain, which weighed 200 to $250 \mathrm{~g}$ were selected randomly; and then prepared for the in-vivo study for their exposure to the antihypercholesterolemia activity test. The appointed (selected) rats were divided into six groups, each comprising seven individual rats. The number of replication can be determined with Federer's Formula. For research with six treatment, the minimum number of replications were four rats. Those six groups were further assigned each for six different allocations concerning the activity test of antihypercholesterol agents (Table 2), 
which consisted of consecutively (1) normal group (the group of test animals that were not given treatment from the beginning to the end of the study); (2) positive control group (simvastatin); (3) negative control group (aqua dest); (4) group treated with porang aquadest before leaching-treatment (unleached porang flour, supposedly with lower glucomannan content), (5) group treated with porang flour after leaching treatment (leached porang flour, supposedly with higher glucomannan content); and (6) group treated with the mixture of leached porang flour $(90 \%)+$ nano-activated carbon $(10 \%)$.

The appointed rats in each group were allowed to acclimatise themselves for two weeks before the antihypercholesterolemia activity test started. During the acclimatisation, the animals were each given daily a standard feed as much as $20 \mathrm{~g}$ and drinking water ad libitum. Afterwards, those acclimatised rats also underwent the socalled induction phase of hypercholesterolemia, which was performed with high-fat feeding (7.5\% egg yolks, $7.5 \%$ goat fat, $85 \%$ standard diet). The induction phase lasted for four weeks or proceeded until the rats revealed their blood cholesterol levels more than 200 $\mathrm{mg} / \mathrm{dL}$. Before the induction-phase treatment (immediately after the 2-week acclimatisation duration), those appointed rats were checked for their blood cholesterol levels using a strip test of the so-called Easy touch ${ }^{\circledR}$ and CHODPAP cholesterol kit, Biolabo ${ }^{\circledR}$. Before the cholesterol-level checking, those rats should undergo the fasting period (without eating and drinking) for more or less $( \pm) 16$ hours. After cholesterol checking, the induction process could begin. Further, after the induction, those inducted rat animals were ready for anti-hypercholesterolemia activity test that comprised those six allocated treatments (Table 2).

That anticholesterol test was performed on the inducted rats for five weeks, whereby the rats in each group were treated (infected) with any of the supposedly anticholesterol agents (i.e. unleached porang flour; leached porang flour exclusively; and the mixture of leach flour and nano activated-carbon) (Table $2)$; and the anticholesterol dosages for each group (designated as F1, F2, and F3) were similar (350 mg/kg BW). While undergoing the anticholesterol test, concurrently all those tested rats also underwent the oral feeding treatment, whereby the rats in each group was fed with high-fat diets, except for the normal group (Table 2). One week after the start of anticholesterol treatment, each of the treated rats was checked for their cholesterol level using Easy touch ${ }^{\circledR}$ 's strip test. When the fiveweek duration for anticholesterol test treatment ended, immediately, the blood of all treated rats was taken to obtain the serum. The obtained serum was used as a sample for measuring the rat's total cholesterol level.

This research that used animal (rats) as a model of a sort was assessed and finally approved by the ethics committee of Bogor Agricultural University under the registered IPB No. 45-2017. Moreover, the experimental procedures with rat objects were in strict accordance with animal ethical committee guidelines as stipulated for the care and use of laboratory animals.

\section{Analysis}

The data was analysed using descriptive qualitative method. The characteristic activated carbon resulted from an average of three replications. The percentage of cholesterol decrease resulted from the average of reduction at one week after treatment and final treatment.

\section{III.RESULTS AND DISCUSSION}

\section{A. Porang's Flour Characteristics}

Characteristics of porang flour generally can be evaluated by its moisture content, ash content, protein content, fat content, and carbohydrate levels. The important data for this research is glucomannan content. Glucomannan content in porang flour after the leaching treatment was $83.96 \%$; confirmed that leaching process using ethanol $50 \%$ and $\mathrm{NaHSO}_{3} 2 \%$ effectively increased the glucomannan content compared to the initial content prior leaching $(32.65 \%)$. 
The glucomannan content of leached porang flour was $83.96 \%$. This value was much higher than the glucomannan content of the previous study conducted by the same leaching treatment (Pasaribu et al., 2016). The glucomannan content of porang flour also was higher than konjac flour extracted from Amorphopallus guripingensis (61.35\%) and Amorphopallus rivirei (72.80\%). They used $50 \%$ of ethanol, followed by further leaching using absolute ethanol at $40^{\circ} \mathrm{C}$ and centrifugation (Huang et al., 2016). Meanwhile, other study revealed that glucomannan could be simply extracted by centrifugation in 1500 $\mathrm{g}$ for 15 minutes at $35^{\circ} \mathrm{C}$ and $75^{\circ} \mathrm{C}$ generated glucomannan contents of $32 \mathrm{~g} / 100 \mathrm{~g}$ and 35 $\mathrm{g} / 100 \mathrm{~g}$, respectively (Tatirat \& Charoenrein, 2011). However, a glucomannan content of this study was lower but still comparable with the result of another study which used $\mathrm{Al}_{2}\left(\mathrm{SO}_{4}\right)_{3}$ and ethanol for purification (Yanuriati et al., 2017). Besides, the temperature of extraction also affected the quality of konjac flour. Extraction of glucomannan using $40 \%$ ethanol at $80^{\circ} \mathrm{C}$ yielded glucomannan content about $90 \%$, the ash content $0.01 \%$, transparency $58 \%$. Therefore, the temperature effect was favourable to improve konjac glucomannan purity (Xu et al., 2014).

\section{B. Characteristic of Nano-Activated Carbon Material}

Characteristics of nano-activated carbon are presented in Table 1. At general, all aspects of nano-activated carbon's properties were within the acceptance limit of Indonesian standard.
The Iod number of obtained nano-activated carbon was much higher from the minimum limit of standard.

Microscopic observation of nano-activated carbon material was performed using scanning electron microscopy (SEM) and the results, as shown in Figure 1. SEM images revealed that the mechanical grinding of activated carbon yielded an irregular form of nanocarbon. However, the mechanical disintegration applied in this study has successfully degraded the size of charcoal into nano-scale (Figure 1).

The characteristics of nano activated-carbon (derived from pine charcoal) concerning its moisture content, ash content, volatile matters, and iod number were in acceptance limit of those as stipulated by the Technical Active Charcoal Standard or Indonesia's National Standard (SNI 06-7370-1995) (Standar Nasional Indonesia, 2013). Activated carbon consists of functional groups bonded to fusedaromatic rings, which would be expected to possess chemical properties similar to those in the aromatic hydrocarbons. Surface functional groups on the carbon matrix can be manipulated and adjusted by thermal, hydro-thermal or chemical treatments for particular functions (Ao et al., 2018).

The high iod number of obtained nano activated-carbon was attributed to the pores structure change during the activation. As the activation time increases, micropores develop at the initial stage of activation. At the second stage, the micropores and the mesopores develop together, and at the third stage, the

Table 1. Characteristic of activated charcoal as the nano-activated carbon material

\begin{tabular}{lcccccc}
\hline \multicolumn{1}{c}{ Item } & $\begin{array}{c}\text { Moisture } \\
\text { content } \\
\mathbf{( \% )}\end{array}$ & $\begin{array}{c}\text { Ash content } \\
\mathbf{( \% )}\end{array}$ & $\begin{array}{c}\text { Volatile } \\
\text { matter } \mathbf{( \% )}\end{array}$ & $\begin{array}{c}\text { Fixed } \\
\text { carbon } \\
\mathbf{( \% )}\end{array}$ & $\begin{array}{c}\text { Degree of } \\
\text { crystalinity } \\
\mathbf{( \% )}\end{array}$ & $\begin{array}{c}\text { Iod number } \\
\mathbf{( m g} / \mathbf{g})\end{array}$ \\
\hline $\begin{array}{l}\text { Nano activated } \\
\text { pine charcoal }\end{array}$ & 13.11 & 4.90 & 3.06 & 92.04 & 49.51 & 843.35 \\
\hline SNI 06-7370-1995 & Max.15 & Max.10 & Max.25 & Min.65 & - & Min.750 \\
(for active carbon) & & & & & & \\
\hline
\end{tabular}

Remarks: $(-)$ not specified; Max $=$ maximum; Min $=$ minimum; $*$ ) the result from an average of 3 replications; $* *)$ interchangeably in this aspect could be regarded as nano activated carbon material 


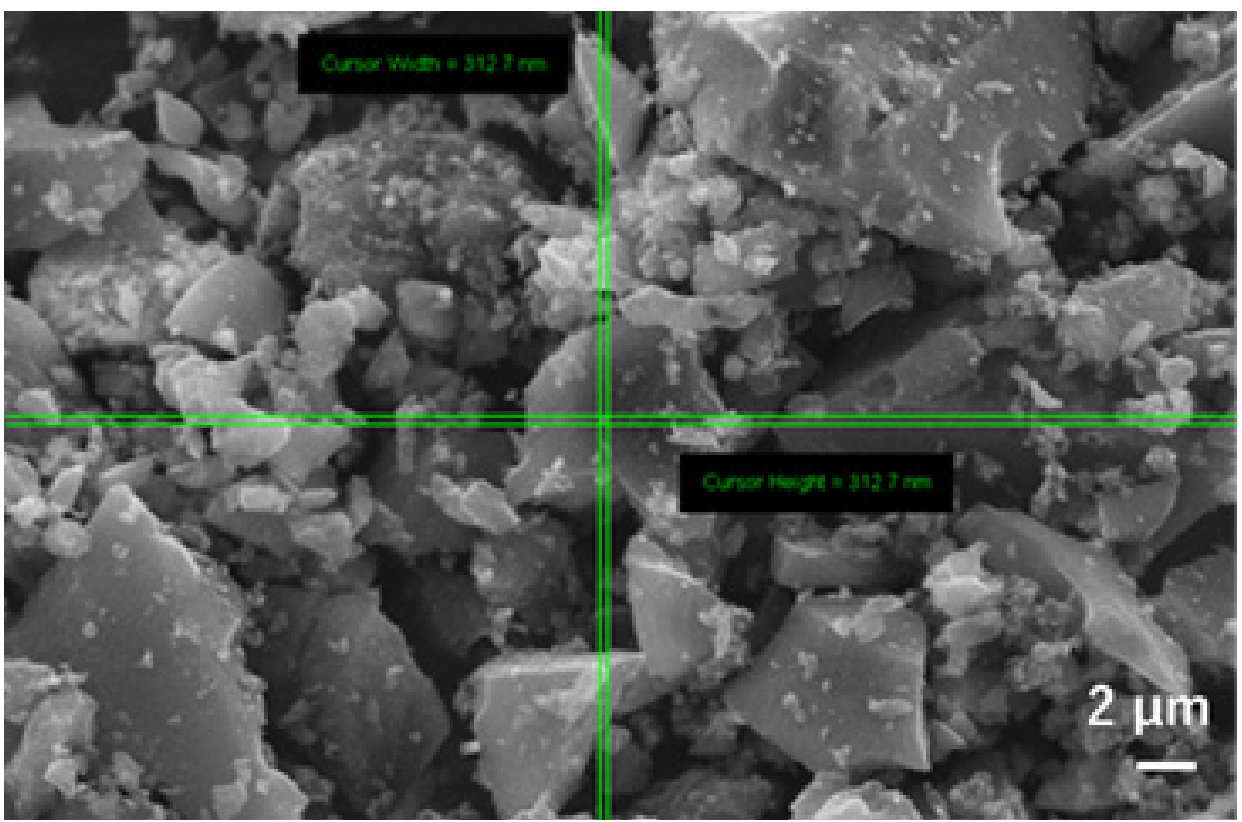

Figure 1. SEM image of nano-activated carbon from pine charcoal (2500x magnification)

mesopores mainly develop with a decrease of the micropores (Lee et al., 2019). The increasing micropores surface area of the activated carbon, the adsorption capacity also increases (Ahmed et al., 2019). With rising temperatures, the porous structures on the surface of the carbon materials and the specific surface area increase, but breakdown and disintegration of the porous structure can happen if the temperature rises too high (Wan \& Hu, 2019). Such degradation and destruction consequently induced the increase in amorphous regions of the activated charcoal, while concurrently caused a decrease in its crystalline regions. In this regard, the crystallinity degree in woods as well as lignocellulose materials, either carbonised, activated, or not, represents the ratio between the crystalline region and the overall region (crystalline + amorphous).

Figure 1 revealed the small fragments and 3D structure with the large specific surface area were obtained after activation at $800^{\circ} \mathrm{C}$, and it is in good accordance with the previous study which conducted activation using $\mathrm{KOH}$ followed by carbonisation at $850^{\circ} \mathrm{C}$ for $2 \mathrm{~h}$ (Awasthi et al., 2019). The high iod number also associated with the adsorption sites of activated carbon. The adsorptive properties of such biomass-derived activated carbons have been utilised as pollution control materials for control of polluting gases (llingworth, Rand, \& Williams, 2019). Activated carbon concept includes several different carbonaceous materials with various structures, forms and size of pores (Volperts et al., 2019). However, the properties of the resulting activated carbon can be influenced by types of activating reagents, activation time, impregnation condition, carbonisation temperature, inorganic impurities and others (Yahya, Al-Qodah, \& Ngah). Besides, the chemical constituents of lignocellulosic materials such as cellulose, hemicellulose and lignin also could influence the properties of activated carbon. Based on the other study, lignin can be considered as being the major contributor of all chars and activated carbons properties (Cagnon et al., 2009).

\section{Antihypercholesterolemia Activity Test}

The anticholesterol performance was represented by the total cholesterol level and its decrease in rat's blood, as presented in Table 2.

Antihypercholesterolemia activity test revealed that the use of porang flour, which 
containing glucomannan was sufficient to decrease total cholesterol level in rat's blood (Table 2). The decreases (in percentage) of overall cholesterol level for the three groups of treatments, which allegedly as anticholesterol agents, were consecutively 18\% (for unleached porang flour/F1, containing low glucomannan), 16\% (for leached porang flour / F2, containing high glucomannan), and $17 \%$ (for leached porang flour that contained high glucomannan, mixed with nano activated-carbon/F3), whereby each of those groups used the same dosages of the alleged anticholesterol agents (350 mg/kg BW).

In the normal group, there was an increase in cholesterol levels. This is thought to be caused by the inadequate $0.01 \%$ PTU solution mixed in drinking water which causes the initial condition of hypercholesterolemic rats to be not maximal. The initial cholesterol of the treatment is still below $100 \mathrm{mg} / \mathrm{dl}$.
By analysing the results from Table 2, the three groups of alleged anticholesterol agents (F1, F2, F3) were seemed to have similar efficacious effect in decreasing the cholesterol level in rats' blood (16-18\%) (Table 2). However, the use of porang flour containing glucomannan performed more effective in the total level of cholesterol than the negative control (14\%). Furthermore, the performance of the alleged anticholesterol agent, represented by F1 group, had a similar percentage of total level cholesterol with the positive control group (using simvastatin as anticholesterol agent) after five weeks of observation. Both are exerting the same cholesterol decreases by about 18\% (Table 2). Simvastatin is the common cholesterol drug used by the community and commercially available.

From the resulting related quantitative figures (Tables 2), it revealed that unleached porang flour/F1 (with $32.65 \%$ glucomannan

Table 2. Total cholesterol level and total cholesterol level decrease in rats' blood due to the antihypercholesterolemia activity test treatment

\begin{tabular}{|c|c|c|c|}
\hline \multirow[b]{2}{*}{$\begin{array}{c}\text { Groups allocated for the } \\
\text { treatment }\end{array}$} & \multicolumn{3}{|c|}{ Antihypercholesterolemia activity test treatment } \\
\hline & $\begin{array}{c}\text { Total cholesterol } \\
\text { level, one week after } \\
\text { the treatment } \\
(\mathrm{mg} / \mathrm{dl})\end{array}$ & $\begin{array}{c}\text { Total cholesterol level, } \\
\text { at final week } \\
\text { of treatment }(5 \\
\text { weeks })(\mathrm{mg} / \mathrm{dl}) \\
\end{array}$ & $\begin{array}{c}\text { Cholesterol } \\
\text { decrease level }(\%)\end{array}$ \\
\hline Normal group & $70.25 \pm 2.99$ & $85.25 \pm 9.07$ & $(21.47 \pm 13.10)$ \\
\hline $\begin{array}{l}\text { Positive control / simvastatin } \\
(\mathrm{C}+)\end{array}$ & $94.25 \pm 16.94$ & $76.00 \pm 11.17$ & $18 \pm 12.45$ \\
\hline Negatif control (C-) & $76.75 \pm 7.63$ & $66.00 \pm 7.16$ & $14 \pm 5.01$ \\
\hline $\begin{array}{l}\text { Unleached porang flour / } \\
\text { without leaching (proved with } \\
\text { low glucomannan content) } \\
\text { dose } 350 \mathrm{mg} / \mathrm{kgBW}(\mathrm{F} 1)\end{array}$ & $79.75 \pm 3.20$ & $65.75 \pm 9.00$ & $18 \pm 10.95$ \\
\hline $\begin{array}{l}\text { Leached porang flour (proved } \\
\text { with high glucomannan } \\
\text { content) }{ }^{1)} \text {, dose } 350 \mathrm{mg} / \mathrm{kgBW} \\
(\mathrm{F} 2)\end{array}$ & $70.00 \pm 4.32$ & $58.75 \pm 5.5$ & $16 \pm 11.22$ \\
\hline $\begin{array}{l}\text { Leached porang flour (proved } \\
\text { with high glucomannan } \\
\text { content) }{ }^{1)}(90 \%)+\text { nano active- } \\
\text { carbon }(10 \%)^{2)} \text {, dose } 350 \mathrm{mg} / \\
\text { kgBW (F3) }\end{array}$ & $80.25 \pm 10.01$ & $67.50 \pm 16.52$ & $17 \pm 11.57$ \\
\hline
\end{tabular}

Remarks: the antihypercholesterolemia activity test treatment lasted for five weeks; ${ }^{1)}$ please refer to Table 1 ; ${ }^{2)}$ interchangeably regarded as nano activated pine charcoal; F1, F2, and F3 considered to be the tested anticholesterol agents 
content) afforded the cholesterol level decrease $(18 \%)$, which was not far different from the leached porang flour with leaching/F2 (with $83.86 \%$ glucomannan) that decreased the cholesterol level decrease about 16\%. The percentages of cholesterol decreased was not far different either the leached porang flour (mixed with active carbon)/F3 that decreased the cholesterol level up to $17 \%$. This results suggested that raw porang flour (containing relatively low glucomannan; without leaching) was quite effective in lowering the total cholesterol level in rats' blood.

The study also assesses the involvement of activated carbon (with its remarkable adsorption capacity) as an anticholesterol agent by combining it with glucomannan. The important physical properties of activated carbon are drug-loaded and wettability. The effectivity of activated carbon influences those as a carrier (Miriyala, Ouyang, Perrie, Lowry, \& Kirby). In this study, the moisture content of nano-activated carbon was $13 \%$. This water might affect the effectiveness of glucomannan as a cholesterol-lowering agent (Malik, 2013).

The other important properties of activated nanocarbon on drug release or delivery system are associated with dissolution and diffusion from the system simultaneously (Mondal, Hoang, Manivasagan, Kim, \& Oh, 2019). Furthermore, the size and the shape of activated nanocarbon also might influence the effectiveness of glucomannan delivery to specific sites as an anticholesterol agent. Based on the other reported study, the promising drug delivery into diseased sites can be achieved through spherical-shaped nanoparticles with a sub-50 nm diameter (Yallappa, Abdul Manaf, \& Hegde, 2018). The morphology of pine activated charcoal in this study was nano-sized, although not uniform in size.

The related research performed by (Yelaware Puttaswamy \& Urooj, 2016) showed the notable performance of mahogany extracts in lowering the cholesterol level in rats' blood. They asserted that aqueous mahogany extracts (using water solvent) which was fed to the rats as much as consecutively $250 \mathrm{mg} \mathrm{kg}-1 \mathrm{BW}$ and $500 \mathrm{mg} \mathrm{kg}^{-1} \mathrm{BW}$ and performed cholesterol level lowering by $38.80 \%$ and $41.04 \%$, respectively. These values were more significant than the cholesterol level lowering value achieved by the positive control (satin), which was $37.31 \%$. However, the cholesterol-lowering level of this study was lower, which were ranged from $16-18 \%$. Furthermore, the effectiveness of glucomannan as an anticholesterol agent in this study was comparable with the capacity of Vitis vinera extracts which could reduce the cholesterol level in 10-21\% (Devi \& Singh, 2017).

\section{CONCLUSION}

The percentage of glucomannan and nano activated-carbon in lowering cholesterol $(17 \%)$ level was not different even slightly lower than the treatment of glucomannan only $(18 \%)$. The leaching pre-treatment on konjac flour did not affect the effectiveness of glucomannan in lowering cholesterol level. The presence of the porous structure of activated carbon has been supposed to be used as a potential substance/ drug carrier. In contrast, the physical properties of activated carbon might be very influential to its performance.

\section{ACKNOWLEDGEMENT}

The authors in this occasion wish to express sincere gratitude, convey high appreciation and feel deeply indebted to the Forest Product Research and Development Center, the Ministry of Environment and Forestry of the Republic of Indonesia, which have supported this research and provided the related facilities and other beneficial items.

\section{AUTHORS' CONTRIBUTIONS}

GP (Gunawan Pasaribu) conceived the study, and inspired his idea to the research entities, especially the research's main cores; GP, TK (Totok K Waluyo), GPi (Gustan Pari), and NH (Novitri Hastuti) designed and carried out the experiments; GP, TK, GPi and NH wrote the 
manuscript. GP serves as the main author.

\section{REFERENCES}

Ahmed, M. B., Johir, M. A. H., Zhou, J. L., Ngo, H. H., Nghiem, L. D., Richardson, C., ... Bryant, M. R. (2019). Activated carbon preparation from biomass feedstock: Clean production and carbon dioxide adsorption. Journal of Cleaner Production, 225, 405-413. doi://10.1016/j.jclepro.2019.03.342.

Ao, W., Fu, J., Mao, X., Kang, Q., Ran, C., Liu, Y., \& Zhang, H. (2018). Microwaveassisted preparation of activated carbon from biomass: A review. Renewable and Sustainable Energy Reviews, 92(April), 958-979. doi://10.1016/j.rser.2018.04.051.

Awasthi, G. P., Bhattarai, D. P., Maharjan, B., Kim, K.-S., Park, C. H., \& Kim, C. S. (2019). Synthesis and characterisations of activated carbon from Wisteria sinensis seed biomass for energy storage applications. Journal of Industrial and Engineering Chemistry, 72, 265272. doi://10.1016/j.jiec.2018.12.027.

Cagnon, B., Py, X., Guillot, A., Stoeckli, F., \& Chambat, G. (2009). Contributions of hemicellulose, cellulose and lignin to the mass and the porous properties of chars and steam activated carbons from various lignocellulosic precursors. Bioresource Technology 100(1), 292298. doi://10.1016/j.biortech.2008.06.009.

Chua, M., Baldwin, T. C., Hocking, T. J., \& Chan, K. (2010). Traditional uses and potential health benefits of Amorphophallus konjac K. Koch ex N.E.Br. Journal of Ethnopharmacology, 128(2), 268-278. doi://10.1016/j.jep.2010.01.021.

Devi, S., \& Singh, R. (2017). Antioxidant and antihypercholesterolemic potential of Vitis vinifera leaves. Pharmacognosy Journal, 9(4), 565-572. doi://10.5530/pj.2017.4.90.

Directorate-General for Food Crops. (2013). Porang/ Iles-Iles (Amorphophallus onchophyllus). Ditjen Pangan, Kementerian Pertanian, Jakarta.

González-Torres, L., Matos, C., Vázquez-Velasco, M., Santos-López, J. A., Sánchez-Martínez, I., García-Fernández, C., Sánchez-Muniz, F. J. (2016). Glucomannan- and glucomannan plus spirulina-enriched pork affect liver fatty acid profile, LDL receptor expression and antioxidant status in Zucker $\mathrm{fa} / \mathrm{fa}$ rats fed atherogenic diets. Food and Nutrition Research, 61(1), 1-14. doi://10.1080/16546628.2017.1 264710.

Huang, H. B., Wang, Y., Jiao, W. Bin, Cai, F. Y., Shen, M., Zhou, S. G., ... Cao, R. (2018). LotusLeaf-Derived Activated-carbon-supported nano-CdS as energy-efficient photocatalysts under visible irradiation. ACS Sustainable Chemistry and Engineering, 6(6), 7871-7879. doi://10.1021/acssuschemeng.8b01021.

Huang, Q., Jin, W., Ye, S., Hu, Y., Wang, Y., Xu, W., ... Li, B. (2016). Comparative studies of konjac flours extracted from Amorphophallus guripingensis and Amorphophallus rivirei: Based on chemical analysis and rheology. Food Hydrocolloids, 57, 209-216. doi://10.1016/j. foodhyd.2016.01.017.

Illingworth, J. M., Rand, B., \& Williams, P. T. (2019). Non-woven fabric activated carbon produced from fibrous waste biomass for sulphur dioxide control. Process Safety and Environmental Protection, 122, 209-220. doi://10.1016/j. psep.2018.12.010.

Indriyani, S., Arisoesilaningsih, E., Widayati, T. \& Purnobasuki, H. 2010. Hubungan faktor lingkungan habitat porang (Amorphophallus muelleri) pada lima agroforestry di Jawa Timur dengan kandungn oksalat umbi. Prosiding Basic Science Seminar VII. FMIPA Universitas Brawijaya, Malang.

Jain, A., \& Tripathi, S. K. (2015). Nanoporous activated carbon from sugarcane waste for supercapacitor application. Journal of Energy Storage, 4, 121-127. doi://10.1016/j. est.2015.09.010.

Lee, H. M., Baek, J., An, K. H., Park, S. J., Park, Y. K., \& Kim, B. J. (2019). Effects of pore structure on n-butane adsorption characteristics of polymer-based activated carbon. Industrial and Engineering Chemistry Research, 58(2), 736-741. doi://10.1021/acs.iecr.8b02715.

Liu, Z., Tabakman, S., \& Welsher, K. (2010). Carbon nanotubes in biology and medicine: in vitro and in vivo detection, imaging and drug delivery. Nano Research, 2(2), 85-120. doi://10.1007/s12274-009-9009-8.

Malik, A.M. (2013). Peran glukomanan- arang aktif sebagai hipokolesterolemia pada tikus sprague dawley. [tesis]. Sekolah Pascasarjana, Institut Pertanian Bogor, Bogor. 
Miriyala, N., Ouyang, D., Perrie, Y., Lowry, D., \& Kirby, D. J. (2017). Activated carbon as a carrier for amorphous drug delivery: Effect of drug characteristics and carrier wettability. European Journal of Pharmaceutics and Biopharmaceutics, 115, 197-205. doi://10.1016/j.ejpb.2017.03.002.

Mondal, S., Hoang, G., Manivasagan, P., Kim, H., \& Oh, J. (2019). Nanostructured hollow hydroxyapatite fabrication by carbon templating for enhanced drug delivery and biomedical applications. Ceramics International, 45(14), 17081-17093. doi://10.1016/j. ceramint.2019.05.260.

Pari, G. (1999). Karakterisasi arang aktif dari arang aktif serbuk gergajian sengon dengan bahan pengaktif $\mathrm{NH}_{4} \mathrm{HCO}$. Buletin Penelitian Hasil Hutan, 17(2), 89-100.

Pasaribu, G., Waluyo, T. K., Hastuti, N., Pari, G., \& Sahara, E. (2016). Peningkatan kualitas tepung porang. Jurnal Penelitian Hasil Hutan, 34(3), 241 248. doi://10.20886/jphh.2016.34.3.241-248.

Sengupta, A., Kelly, S. C., Dwivedi, N., Thadhani, N., \& Prausnitz, M. R. (2014). Efficient intracellular delivery of molecules with high cell viability using nanosecond-pulsed laseractivated carbon nanoparticles. ACS Nano, 8(3), 2889-2899. doi://10.1021/nn500100x.

Shao, W., Arghya, P., Yiyong, M., Rodes, L., \& Prakash, S. (2013). Carbon nanotubes for use in medicine: Potentials and limitations. Syntheses and Applications of Carbon Nanotubes and Their Composites. doi://10.5772/51785.

Standar Nasional Indonesia (SNI 7939). (2013). Serpih porang. Badan Standardisasi Nasional.

Tatirat, O., \& Charoenrein, S. (2011).Physicochemical properties of konjac glucomannan extracted from konjac flour by a simple centrifugation process. LWT - Food Science and Technology, 44(10), 2059-2063. doi://10.1016/j. lwt.2011.07.019.

Tester, R., \& Al-Ghazzewi, F. (2017). Glucomannans and nutrition. Food Hydrocolloids, 68, 246-254. doi://10.1016/j.foodhyd.2016.05.017.

Tester, R. F., \& Al-Ghazzewi, F. H. (2013). Mannans and health, with a special focus on glucomannans. Food Research International, 50(1), 384-391. doi://10.1016/j. foodres.2012.10.037.
Volperts, A., Plavniece, A., Dobele, G., Zhurinsh, A., Kruusenberg, I., Kaare, K., ... Norkus, E. (2019). Biomass-based activated carbons for fuel cells. 141, 40-45. doi://10.1016/j. renene.2019.04.002.

Wan, H., \& Hu, X. (2019). From biomass-derived wastes (bagasse, wheat straw and shavings) to activated carbon with three-dimensional connected architecture and porous structure for Li-ion batteries. Chemical Physics, 521(January), 108-114. doi://10.1016/j. chemphys.2019.01.012.

Xu, W., Wang, S., Ye, T., Jin, W., Liu, J., Lei, J., ... Wang, C. (2014). A simple and feasible approach to purify konjac glucomannan from konjac flour - Temperature effect. Food Chemistry, 158, 171-176. doi://10.1016/j. foodchem.2014.02.093.

Yahya, M. A., Al-Qodah, Z., \& Ngah, C. W. Z. (2015). Agricultural bio-waste materials as potential sustainable precursors used for activated carbon production: A review. Renewable and Sustainable Energy Reviens, 46, 218-235. doi://10.1016/j.rser.2015.02.051.

Yallappa, S., Abdul Manaf, S., \& Hegde, G. (2018). Synthesis of a biocompatible nanoporous carbon and its conjugation with fluorescent dye for cellular imaging and targeted drug delivery to cancer cells. New Carbon Materials, 33(2), 162-172. doi://10.1016/S18725805(18)60332-4.

Yanuriati, A., Marseno, D. W., Rochmadi, \& Harmayani, E. (2017). Characteristics of glucomannan isolated from the fresh tuber of porang (Amorphophallus muelleri Blume). Carbobydrate Polymers, 156, 56-63. doi://10.1016/j.carbpol.2016.08.080.

Yelaware Puttaswamy, N., \& Urooj, A. (2016). In vivo antihypercholesterolemic potential of swietenia mahagoni leaf extract. Cholesterol, 2016. doi://10.1155/2016/2048341.

Zeng, Z., Li, X., Zhang, S., \& Huang, D. (2017). Characterisation of nano bamboo charcoal drug delivery system for Eucommia ulmoides extract and its anticancer effect in vitro. Pharmacognosy Magazine, 13(51), 498-503. doi://10.4103\%2Fpm.pm_256_16. 